\title{
Development of Anecdote Text Module Based on Interactive Multimedia in State of Vocational High School 1 Batang Toru
}

\author{
Riska Damayanti ${ }^{1}$, M. Oky Fardian Gafari², Syahnan Daulay ${ }^{2}$ \\ ${ }^{I}$ Master Student in State University of Medan (UNIMED), Indonesia \\ ${ }^{2}$ Lecturer in State University of Medan (UNIMED), Indonesia \\ Riskadamayanti882@gmail.com
}

\begin{abstract}
This study aims is to determine the results of the development of interactive multimedia-based anecdotal text learning modules by students State of Vocational High School 1 of Batang Toru. The module developed is in the form of a digital module. This type of research is development research based on the 4-D development model. With the subject of the trial consisting of design experts, material experts, Indonesian language teachers, and class X students of State of Vocational High School 1 Batang Toru. The results showed that (1) the validation of the material experts included the content eligibility is $88.0 \%$ in the good category, the feasibility of presenting is $93.7 \%$ learning module Very good category, Interactive Mutimedia aspects is $95.8 \%$ very good category, language assessment aspects 92, $5 \%$ category is very good, and aspects of project based learning is $83.3 \%$ Good category (2) validation of design experts includes initial design is $89.2 \%$ with good category, content design is $83.9 \%$ good category, digital module typography is 83.3 category good, and $87.5 \%$ illustration in good category. (3) limited trials obtained a score is $82.79 \%$ with good criteria. (4) Expanded trials obtained a score is $80.04 \%$ in the good category. The difference obtained was 13 from before and after using a digital module. This research has implications, namely the module developed will contribute to the practice, especially in the implementation of the learning process for teachers as additional teaching materials to provide convenience to the material being taught can be independent or classical.
\end{abstract}

Keywords : Digital Modules and Anecdotal Texts .

\section{Introduction}

Indonesian language learning currently uses the 2013 curriculum with text content. Textbased learning is able to help students improve their knowledge and abilities in the learning process. This is evidenced by Wardani's research (2017: 69) text-based learning can be used in forming religious, social, knowledge and skills attitudes. Therefore, text-based learning is used as the basis for developing basic competencies in Indonesian language subjects and skills in the 2013 curriculum.

The 2013 curriculum in learning Indonesian has many changes both in terms of content, the way of presentation and evaluation used. In terms of content, Indonesian language learning displays several texts that are truly new in learning, such as anecdotal texts, abstract texts, negotiating texts and so on. In terms of presentation, the 2013 curriculum presents text-based material that is used as a model in studying material. Based on the text given, students are asked to be able to understand the concepts and rules that apply in a text. One of the things students must understand is anecdotal text.

Anecdotal text is one of the new material in Indonesian language learning which is in the semester X class of vocational high school /Senior high school / Islamic high school . Anecdotal text is a short, funny, poignant and meaningful story. It is commensurate with the research of Damayanti et al (2014: 2) states "Anecdotal text is an interesting, funny and impressive short story, usually about important or famous people and based on actual events. Anecdotal texts are very important for students to learn, in addition to being funny in 
expressing criticism in a subtle and meaningful way, commensurate with Gumelar's research (2018: 117) states anecdotal text as one of the genre of texts students must learn because it leads to the emergence of positive effects for students. Anecdotal texts are a means of developing and improving language competence, language, literature, mastery of other subject competencies, as well as the formation of noble characters in character formation".

Regarding the learning of anecdotal texts, students still experience difficulties, especially when given the task of writing anecdotal texts. Based on the results of observations and interviews conducted by researchers at State of Vocational High School 1 Batang Toru on October 7, 2018 shows that writing anecdotal texts on students is difficult to determine the topic, it is difficult to put his ideas into writing. The results of the interview with one of the Indonesian language teachers stated that writing of class $\mathrm{X}$ anecdotal texts was still below the value of Minimum Completion Criteria (KKM) that applies in the school is 75 , and $40 \%$ of students were active in writing anecdotal texts. Reinforced by Wardani et al (2016: 170) research "students are often confused in placing sequences of text based on structure, students find it difficult to find anecdotal ideas and $40 \%$ of students who are active in learning to write anecdotal texts.

Departing from these facts, researchers will use the module as a learning resource for students who have advantages in improving students' abilities. This is reinforced by Nugreheni (2007: 240) said, "Learning with modules allows one student who has high speed in learning will more quickly complete one or more Basic Competencies (KD) compared with other students. Modules containing material, methods, boundaries, and ways of evaluating are designed systematically and attractively to achieve the expected competencies. Furthermore, Prastowo (2015: 204) states that "modules are basically teaching materials arranged systematically in a language that is easy to understand and in accordance with the level of knowledge and age of students. In addition, the existence of modules can also measure students' ability to master a material."

Modules are developed with the help of interactive multimedia, the goal is that students more easily write anecdotal texts assisted by images, animations, videos, sounds into writing. Teaching materials will be arranged in the form of digital modules that can be studied independently through a computer. The development of learning modules is more interesting and creative. The digital module is easy to carry anywhere because it is in the form of a CD and can be seen anywhere so that student learning increases. In line with the opinion of Nyoman et al (2012: 15) packaging material in the form of software program modules that combine video and audio, which includes: film footage about phenomena/ problems in the student's environment, texts that can stimulate students to think about concepts, simulations able to enhance students' abstract thinking, and will be an alternative for students in developing independent learning methods for students. Program packaging results hereinafter referred to as Module based Interactive Multimedia. The multimedia program module can then be stored on a PC hardisk, so that at home students can open it whenever needed. For students who have laptops, modules can also be stored on their laptops, so they can be taken anywhere. In addition, with the development of ICT which has entered various fields of life including the world of education, the module program interactive multimedia can be packaged in $e$ book archives in the form of winzip or winrar, then stored on a website or blog, so that the module can be accessed by anyone, from where and at any time according to their wishes and needs.

Interactive multimedia learning is a combined use of several media that convey information in the form of text, graphics or animated graphics, movies, videos, and audio. This 
is evidenced by Dongson (2005: 150) in his journal entitled "The American Journal of Distance Education" stating that:

Three types of interaction in learning "learner instructor, learner and learner-content. In learner-intraction is a major factor accounting for cognitive learning. Learner-learner interaction fosters colloborative learning. Learner Content Interaction Interactive Learning Activities.

Research on interactive multimedia is feasible in the learning process. This is evidenced by previous research by Amrulloh et al (2013: 135) in his journal stating that the multimedia feasibility is interactive in terms of two aspects, namely the feasibility of the material which includes the suitability of media content with the concept of mutation, and the suitability of media content with learning objectives.

Referring to several expert opinions above, it can be concluded that interactive multimedia learning can facilitate teachers and students in the teaching and learning process.

The objectives in this development are to: 1. Describe the process of developing interactive multimedia-based anecdotal text learning modules for students at SMK Negeri 1 Batang Toru. 2. Describe the feasibility of interactive multimedia-based anecdotal text learning modules to students of SMK Negeri 1 Batang Toru. 3. Describe the effectiveness of interactive multimedia-based anecdotal text learning modules in students of SMK Negeri 1 Batang Toru.

\section{Research Method}

This research was conducted at State of Vocational High School 1 Batang Toru in class X Learning Year 2018/2019. The type of research used is the type of research and development $(\mathrm{R} \& \mathrm{D})$. The research anddevelopment $(\mathrm{R} \& \mathrm{D})$ model is a research model used to produce certain products and test the effectiveness of these products. The development research model used in this study is a model 4-D. Abbreviation of Define, Design, Develop, and Desseminate .

The data obtained is sata about validation of interactive multimedia-based modules on anecdotal text writing lessons. This data was collected through material expert validation, validation of learning design experts (media experts) and questionnaires given to Indonesian language teachers in class X Vocational High School. Questionnaire validation is given to the validator, individual trials, small group trials, and limited group trials presented in the form of Likers Scale which has been given a score of 4.3, 2.1. Then the data were analyzed quantitatively descriptive, namely calculating the percentage of indicators for each of the instructional materials developed.

\section{Result and Discussion}

The application procedure for the development of interactive multimedia-based anecdotal text learning modules is carried out in stages. The first procedure in the implementation of this development is to analyze the needs of 2 teachers and 23 students with the method outlining the questionnaire so that respondents have an overview of the statements in the questionnaire submitted. The results of the implementation of questionnaires were obtained by $100 \%$ of teachers requiring interactive multimedia-based modules so that the learning process was effective, and $100 \%$ of students said that they needed interactive multimedia-based modules so that they became married as an individual learning tool. The results of the needs analysis data are presented as follows: Table 1 
Table. 1 Data Needs Analysis

\begin{tabular}{|c|c|c|c|c|}
\hline \multirow[t]{2}{*}{ No. } & \multirow[t]{2}{*}{ A list of questions } & \multirow[t]{2}{*}{ Answer } & \multicolumn{2}{|c|}{ Frequency } \\
\hline & & & Teacher & Students \\
\hline \multirow[t]{2}{*}{1} & \multirow{2}{*}{$\begin{array}{lr}\text { Have } & \text { known } \\
\text { interactive } & \\
\text { multimedia } & \text { based } \\
\text { modules } & \end{array}$} & Yes & 1 & 0 \\
\hline & & Not & 1 & 23 \\
\hline \multicolumn{3}{|c|}{ Percentage of Scores } & $50 \%$ & $100 \%$ \\
\hline \multirow[t]{2}{*}{2} & \multirow{2}{*}{$\begin{array}{l}\text { Using interactive } \\
\text { multimedia modules } \\
\text { in the learning } \\
\text { process }\end{array}$} & Yes & 0 & 0 \\
\hline & & Not & 2 & 23 \\
\hline \multicolumn{3}{|c|}{ Percentage of Scores } & $100 \%$ & $100 \%$ \\
\hline \multirow[t]{2}{*}{3} & \multirow{2}{*}{$\begin{array}{l}\text { The need for } \\
\text { interactive } \\
\text { multimedia based } \\
\text { modules }\end{array}$} & Yes & 2 & 21 \\
\hline & & Not & 0 & 2 \\
\hline \multicolumn{3}{|c|}{ Percentage of Scores } & $100 \%$ & $91 \%$ \\
\hline
\end{tabular}

Based on the results of student and teacher responses about teaching materials. Then the need for teaching materials in the form of ineractive multimedia-based modules to facilitate students in understanding anecdotal texts. Because using interactive multimedia-based modules will be attractive to students because it will stimulate students' audio visuals and for teachers it will facilitate the learning process.

Material feasibility analysis and design feasibility analysis are needed by material experts and design experts to assess the feasibility of interactive multimedia-based modules .

Table. 2 Results of Validation on Aspects of Learning Design

\begin{tabular}{|c|l|c|c|c|}
\hline No. & \multicolumn{1}{|c|}{ Aspect } & $\begin{array}{c}\text { Rating } \\
\text { Score }\end{array}$ & Percentage & Criteria \\
\hline 1 & Initial Design & 51 & $89.2 \%$ & Well \\
\hline 2 & Content Design & 47 & $83.9 \%$ & Well \\
\hline 3 & Typography of digital modules & 20 & $83.3 \%$ & Well \\
\hline 4 & Illustration Contents & 21 & $87.5 \%$ & Well \\
\hline Average Earnings Percentage & $\mathbf{8 5 . 9 \%}$ & Well \\
\hline
\end{tabular}

Table. 3 Validasi Analysis of Aspects of Learning Materials

\begin{tabular}{|c|l|c|c|c|}
\hline No. & \multicolumn{1}{|c|}{ Aspect } & $\begin{array}{c}\text { Number of } \\
\text { Assessment } \\
\text { Scores }\end{array}$ & Percentage & Criteria \\
\hline 1 & Content Feasibility & 78 & $88.0 \%$ & Well \\
\hline 2 & $\begin{array}{l}\text { Feasibility of Presentation } \\
\text { of Learning Modules }\end{array}$ & 90 & $93.7 \%$ & Very good \\
\hline 3 & $\begin{array}{l}\text { Interactive multimedia } \\
\text { aspects }\end{array}$ & 48 & $95.8 \%$ & Very good \\
\hline
\end{tabular}




\begin{tabular}{|c|l|c|c|c|}
\hline 4 & $\begin{array}{l}\text { Language Assessment } \\
\text { Aspects }\end{array}$ & 74 & $92.5 \%$ & Very good \\
\hline 5 & $\begin{array}{l}\text { Aspects of Project Based } \\
\text { Learning }\end{array}$ & 40 & $83.3 \%$ & Well \\
\hline \multicolumn{3}{|l|}{ Average Earnings Percentage } & $\mathbf{9 0 . 6 6 \%}$ & Very good \\
\hline
\end{tabular}

From the results of expert material analysis and learning design, interactive multimediabased modules are appropriate to use in the learning process.

The effectiveness of interactive multimedia based modules requires data on student learning outcomes in the learning process using digital modules.

Table. 4 Distribution of Pretest Value Frequency Results of Learning to Write Anecdotal Texts before Using Digital Modules

\begin{tabular}{|c|c|c|}
\hline Interval & Frequency & Presentation \\
\hline $55-59$ & 5 & $21.7 \%$ \\
\hline $60-64$ & 3 & $13 \%$ \\
\hline $65-69$ & 4 & $17.3 \%$ \\
\hline $70-74$ & 3 & $13 \%$ \\
\hline $75-79$ & 4 & $17.3 \%$ \\
\hline $80-84$ & 4 & $17.3 \%$ \\
\hline$\sum$ & $\mathbf{2 3}$ & $\mathbf{1 0 0 \%}$ \\
\hline
\end{tabular}

Table. 5 Distribution of Frequency Value of Posttest of Learning Outcomes Writing Anecdotal Text Using Interactive Multimedia Based Modules

\begin{tabular}{|c|c|c|}
\hline Interval & Frequency & Presentation \\
\hline $65-69$ & 2 & $8.69 \%$ \\
\hline $70-74$ & 1 & $4.34 \%$ \\
\hline $75-79$ & 5 & $21.7 \%$ \\
\hline $80-84$ & 5 & $21.7 \%$ \\
\hline $85-89$ & 5 & $21.7 \%$ \\
\hline $90-94$ & 5 & $21.7 \%$ \\
\hline$\sum$ & $\mathbf{2 3}$ & $\mathbf{1 0 0 \%}$ \\
\hline
\end{tabular}

Judging from the distribution results the frequency of the pretest values of the results of learning to write anecdotal text before using interactive multimedia-based modules very low. And after using interactive multimedia-based modules increases.

\section{Discussion}

Discussion The results development of anecdotal text-based learning module multi $\mathrm{m}$ e he interakti $\mathrm{f}$. This development research is directed to produce a product in the form of an interactive multimedia module in anecdotal text used to improve the anecdotal text learning process and student competency. Therefore, this study was conducted and begins with (1) The definition phase(define) which at this stage kebutuham derived from the analysis, requirements analysis for interactive multimedi based modules transform the needs of students $91 \%$ and $100 \%$ of the teachers require ber4basis interactive multimedia modules. (2) the design 
stage ( design ) that is seen from student learning outcomes before using a digital module. Where before using interactive multimedia-based modules students get scores below 75. Where the Indonesian language KKM is $75,65 \%$ of students score below KKM 75. So the need for additional teaching materials is called interactive multimedia-based modules to improve students' ability to write anecdotal texts . (3) development stage ( depelopment) where at this stage of development is seen from the validation test of the team of material experts and design experts. Before learning is done using interactive multimedia-based modules required a validation team of material experts and design experts for the feasibility of interactive multimedia-based modules. for material feasibility the average score is $90.66 \%$ with very good material while the feasibility of design is scored $85.9 \%$ with good category. then from the feasibility of the material and design it is worth testing. In this trial conducted on the experimental class, the X-TGB class with 23 students received a score of $84 \%$ above the criteria of minimum completeness (KKM) is 75 . From the results of the student's scores it was said to be effective by using interactive multimedia-based modules in anecdotal text learning. (4) The deployment phase (disseminate) is a module-based deployment using interactive multimedia, ie 95 people for all class X SMK Negeri 1 Batang toru. From the results of the dissemination it turns out the results are the same as the experimental class, where the average student score is $\mathbf{7 5}$. So the interactive multimedia-based learning module is suitable for use in the learning process of writing anecdotal text.

\section{Conclusion}

Based on the description of the results of the study, it can be stated the conclusions relating to the development of interactive multimedia-based anecdotal text learning modules for students of State of Vocational High School 1 Batang Toru, conclusions obtained based on research objectives, results, and discussion, can be described as follows:

1. The results of the development of interactive multimedia-based anecdotal text learning modules with the application of project based learning based on needs analysis states that the development of interactive multimedia-based modules is needed by teachers and students in the learning process with the latest curriculum provisions by the government and adds students' interest in learning.

2. The use of active multimedia-based anecdotal text learning modules with the application of project based learning is more effective than the printed modules used by students. This is evidenced by better student learning outcomes, namely the use of $65 \%$ textbooks (pretest) with sufficient categories and the use of interactive multimedia-based learning modules with the application of project based learning (Postest) of $84 \%$. The effectiveness of interactive multimedia-based modules based on the pretest and posttest test of writing anecdotal texts increased with a difference of $13 \%$ and digital module products in the form of interactive multimedia-based modules in anecdotal text writing material at State of Vocational High School 1 Batang Toru.

\section{Suggestion}

The findings described in the conclusion of the results of the research on digital module development with the implementation of project based learning, the following are some suggestions as follows: 
1. Interactive multimedia based anecdote learning module with the application of project based learning, is expected to be used in the learning process outside and inside the classroom and can help students understand the learning material, and be able to open up students' insight into independent learning.

2. The product of the research results of teaching materials in the form of interactive multimedia-based anecdotal text modules is expected to be used as a reference for the development of teaching materials for digital-based content.

The results of this study are expected to be able to do further research and in-depth about anecdotal text learning, the need for cooperation between educational institutions because in this study the limitations and need to be followed up in the steps of this study by conducting the same study, but at locations and schools different, which can play a role in enriching and adding additional data on cases of educational institutions to be used as evaluation material.

\section{References}

Ambarita dan Feliks. 2018. Terampil Berdiskusi, Menulis Paragraf yang Efektif, Aliran dalam Sastra dan Bebera Istilah-istilah. Bandung: Alfabeta.

Amrulloh Rizki, et al. 2013.Kelayakan Teoritis Media Pembelajaran Multimedia Interaktif Materi Mutasi untuk SMA. Jurnal Berkala Ilmiah Pendikan Bilogi. Vol. 2 No 2

Arda, et al. 2015. Pengembangan Media Pembelajaran Interaktif Berbasis Komputer untuk siswa SMP kelas. VIII. Vol.3. No.1

Arikunto, Suharsimi. 2013. Dasar-Dasar Evaluasi Pendidikan. Jakarta: Bumi Aksara

Arsyad, Andi. 2002. Media Pembelajaran. Jakarta: PT Raja Grafindo Persada.

Bardi Jailani. 2015. Pengembangan Multimedia Berbasis Komputer untuk Pembelajaran Matematika bagi siswa SMA. Jurnal Inovasi Teknologi Pendidikan. Vol.2 No.1

Branch, Robert Maribe. 2009. Instructinal Design: The Addie Approach. USA:Springer.

Damayanti, et al. 2014. Pembelajaran Menulis Teks Anekdot Berpendakatan Saintifik dengan Model Pembelajaran Berbasis Proyek (Project Based Learning) pada Siswa Kelas X Tata Kecantikan Kulit 1 di SMK Negeri 2 Singaraja. Jurnal Pendidikan Bahasa dan Sastra Indonesia. Vol. 2 No. 1

Depdiknas. 2008. Penulisan Modul. Jakarta: Depdiknas.

Dongson. 2005. Interactive Multimedia Based E. Learning: A Sudy Of Effectiveness Journal of Distance Education.

Gumelar, dan Mulyati. 2017. Meme: Dapatkah Meningkatkan Kemampuan Siswa dalam Menulis Teks Anekdot. Jurnal Sains Sosial dan Humaniora, Vol.2 No. 1

Hamdani. 2011. Strategi Belajar Mengajar. Bandung: Pustaka Setia

Irwandani. 2017. Modul Digital Interaltif Berbasis Articulate Studio 13: Pengembangan pada materi gerak melingkah X. Vol.6. No.2

Kemendibud.2016. Buku Guru: Bahasa Indonesia Ekspresi diri dan Akademik. Jakarta: Kemendikbud.

Lori L. Scarlatos. 2010. Designing Interactive Multimedia. Journal researchgate. Vol. 97. No. 2

Lubis, Mina syanti et al. 2015. Pengembangan Modul Pembelajaran Bahasa Indonesia Berbantuan Peta Pikiran pada Materi Menulis Makalah Siswa Kelas XI SMA/MA. Jurnal Bahasa, Sastra, dan Pembelajaran, Vol.2 No.1

M. Taufik Aditia. Novianti Muspiroh. 2013. Pengembangan Modul Pembelajaran Berbasis Sains, Lingkungan, Teknologi, Masyarakat, dan Islam (salingtematis) dalam 
Meningkatkan Hasil Belajar Siswa pada Konsep Ekosistem Kelas X di SMA NU (Nadhatul Ulama) Lemahabang Kabupaten Cirebon. Jurnal Scientiae Educatia. Volume 2. Edition2.

Majid. Abdul. 2011. Perencanaan Pembelajaran: Mengembangankan Stnadar Kompetensi guru: Bandung: PT Remaja Rosda Karya

Mardiani Evi, et al. 2015. Penyusunan Modul Pembelajaran Jaringan Tumbuhan Berbasis Hakikat Sains. Jurnal Biodidaktika. Volume 10. No 2.

Munir. 2015. Multimedia:konsep \& Aplikasi dalam Pendidkan. Bandung: Alfabeta.

Norlidah Alias. Development of Health Education Learning Module in Bac. TSELDPE Programme in TTI: Needs Analysis Study. The Malaysian Online Jurnal of Educational Science. Volume 3 - Issue 1.

Nugraheni, B. Indah 2007. Pngembangan Multimedia Interaktif Pembelajaran Mata Kuliah Akutansi Dasar 1. Jurnal Pendidikan dan Evaluasi Pendidikan. Vol. 1 No. 1

Putri, Hilda. 2017. Pengembangan Modul Berbasis Pendekatan Kontekstual untuk Pembelajaran Menulis Teks Anekdot. Jurnal Pendidikan Bahasa dan Sastra Indonesi, Vol. 17, No. 2

Rita dan Julaga Situmorang. 2014. Pengembangan Pembelajaran Multimedia Interaktif Berbasis Internet Pelajaran Bahasa Inggris. PPS Universitas Negeri Medan. Jurnal teknologi informasi \& Komunikasi dalam pendidikan. Vol 4. No. 1

Sugiyono. 2010. Metode Penelitian Kuantitatif dan Kualitatif dan R\&D. Bandung: Alfabeta.

Wardani, dkk. Analisis Teks Anekdot Bermuatan Karakter dan Kearifan Lokal Sebagai Pengayaan Bahan Ajar Bahasa Indonesia di SMA. Jurnal Pendidikan Bahasa dan Sastra Indonesia. Vol.6 No. 2 